Prof. dr Brane Mikanović, vanredni profesor

Originalni naučni rad

Msr Kristijan Popovićz , viši asistent

UDK: 37.013 .78

Univerzitet u Banjoj Luci

Filozofski fakultet

DOI: $10.5937 /$ IstrPed2102351M

\title{
KONSTRUKCIJA I PROVERA SKALE SOCIJALNE UKLJUČENOSTI I ISKLJUČENOSTI STUDENATA
}

\begin{abstract}
Rezime: Cilj rada je da se konstruiše skala za merenje socijalne kompetentnosti studenata, koja ima prihvatljivu (visoku) pouzdanost. Uzorak istraživanja čini 222 studenta, starosti između 19 i 28 godina $(M=22,41 ; S D=1,66)$. Uz ajteme je ponuđena petostepena skala kojom ispitanici procenjuju stepen saglasnosti sa sadržajem usmerenim na socijalnu uključenost i/ili socijalnu isključenost. Konačnu verziju instrumenta određuju dve zasebne skale, socijalna uključenost sa 12 i socijalna isključenost sa 14 ajtema. Dobijeni koeficijenti pouzdanosti za obe skale su zadovoljavajući, $a=0,83$ za skalu socijalne uključenosti i $a=0,86$ za skalu socijalne isključenosti. $U$ proveri diskriminativnosti utvrđeno je da postoji pomeranje skorova prema višim vrednostima na skali socijalne uključenosti $(S=-0,97, K u=1,12)$ dok distribucija skorova na skali socijalne isključenosti, prema istim parametrima, ne odstupa značajno od normalne $(\mathrm{S}=0,52, \mathrm{Ku}=0,25)$. Kolmogorov-Smirnov test $(\mathrm{K}-\mathrm{S}=1,50$, $\mathrm{p}<.05)$ potvrđuje statistički značajno odstupanje skorova od normalne distribucije na skali socijalne uključenosti. Obe skale su predstavljene glavnim komponentama koje varijansu objašnjavaju sa $37,57 \%$ zasićenosti, dok sa sumativnim skorovima ostvaruju korelaciju r=0,99. Preliminarni rezultati ukazuju da su predstavljene karakteristike skale zadovoljavajuće. Naredni koraci u potpunoj validaciji skale i njenog korištenja kao konstruisanog istraživačkog instrumenta, sa utvrđenim mernim karakteristikama, podrazumevaju proveru skale na drugim uzorcima i ispitivanje odnosa sa relevantnim spoljnim kriterijskim varijablama.
\end{abstract}

Ključne reči: skala, socijalna isključenost, socijalna uključenost.

Uvod

Priroda socijalnih odnosa, kao i njihovi efekti zavise od prirode pojedinca i od socijalnog konteksta u kome se pojedinac nalazi. Tako se socijalna uključenost i socijalna isključenost najčešće u stručnoj i naučnoj literaturi određuju kao vidljivo socijalno stanje pojedinca ili određene grupe.

Socijalnu uključenost i socijalnu isključenost možemo posmatrati kao krajnje antipode na kontinuumu SU-SI. Otuda bi svako pomeranje ličnosti na tom kontinuumu značilo smanjenje jednog i povećanje drugog socijalnog statusa. Ipak treba razlikovati socijalnu uključenost i socijalnu isključenost koju pojedinac ima u određenoj socijalnoj grupi ili okruženju, od one socijalne uključenosti i socijalne isključenosti koju pojedinac doživljava i predstavlja sam. U oba slučaja moguće je govoriti o pozitivnom i negativnom značenju socijalne uključenosti i socijalne isključenosti. Zapravo, pojedinac ili određena grupa u isto vreme mogu imati status socijalne uključenosti, kao i status socijalne isključenosti. Na primer, pojedinac može biti izuzetno pozitivno

${ }^{1}$ brane.mikanovic@ff.unibl.org

${ }^{2}$ kristijan.popovic@ff.unibl.org 
prihvaćen u porodici i slabo prihvaćen u školi ili razredu (Klarin, 2004). Socijalnu uključenost i socijalnu isključenost moramo posmatrati kao višedimenzionalni proces, na koga utiču brojni faktori. Socijalno uključivanje najčešće se definiše kao „svako socijalno ponašanje koje doprinosi dobrobiti drugog pojedinca ili grupe, bez obzira na stepen ili vrstu lične dobiti ili žrtve, odnosno sa malom mogućnošću recipročne materijalne ili socijalne nagrade" (Krnjajić, 2002: 100). Zato se ovako ponašanje pozitivno vrednuje u socijalnim interakcijama. Upravo pozitivni socijalni odnosi su osnova za zadovoljstvo i uspeh za uključivanje u društveno okruženje.

Socijalnu isključenost određujemo kao „kontinuirano i postepeno isključivanje iz punog učešća u socijalnim aktivnostima" (Zubac, 2020: 322). Ovako neodgovarajuća veza između pojedinca i društva predstavlja nemogućnost pojedinca da se integriše u socijalnu sredinu. Ona najčešće nastaje kada se pojedinac ili grupa prinudno ili dobrovoljno izdvajaju (isključuju, udaljavaju) iz određene sredine i kada nastaje prekid veza i odnosa sa drugim ljudima ili grupama (Šućur, 2004). Brojni su razlozi zbog kojih pojedinac ili grupa mogu biti isključeni, a posebno su izdvajaju psihološki i situacioni (MacuraMilovanović, 2010). U razloge psihološke prirode ubrajamo: osećanje krivice, osećanje manje vrednosti, stid, sram, nepoverenje, konflikte, nasilje. Situacioni razlozi mogu biti: novo školsko okruženje, život u novoj kulturi (jezik, tradicija, običaji), ratni period, bolest, zatvor. Socijalnoj isključenosti doprinosi umanjenje prava pojedinca, na primer kao što su: pravo na obrazovanje, pravo na rad, pravo na materijalno obeštećenje i slično. Socijalna isključenost slabi veze pojedinca sa okruženjem (Kobolt, 2010). Uopšteno rečeno, pojedinci i socijalne grupe su socijalno isključeni ako se nalaze u nepovoljnom položaju, u bilo kom smislu (porodičnom, ekonomskom, socijalnom, obrazovnom, zdravstvenom).

Kristina Urbanc (2006) ukazuje na značaj poznavanja jedinstvenosti pojedinca u unapređivanju rada socijalnog pedagoga. Upravo tu jedinstvenost pojedinca treba uzeti u obzir prilikom nastojanja da se on usmeri od socijalne isključenosti ka socijalnoj uključenosti. Odnosu prema pojedincima koji se kreću od socijalne isključenosti ka socijalnoj uključenosti može doprineti sledeće:

- ophoditi se prema korisniku kao prema pojedincu, izbegavajući klasifikacije;

- ohrabrivati korisnika da učestvuje u procesu planiranih promena;

- otkrivati i koristiti korisnikove potencijale;

- podržavati poverenje korisnika u sebe i u okruženje i

- negovati korisnikovo dostojanstvo kroz vlastitu komunikaciju (prema: Urbanc, 2006).

Proces razvoja i vaspitanja uvek podrazumeva pozitivne promene. Zbog toga „u procesu razmatranja socijalnopedagoške delatnosti potrebno je poći od osnovne pretpostavke prema kojoj je svaka pedagoška delatnost, pre svega, usmerena na podsticanje celovitog razvoja pojedinca koja, uz primenu integralnog pristupa tom razvoju, treba da omogući pojedincu da vlastite potrebe zadovoljava u skladu sa normama društvene zajednice" (Jevtić i Knežević-Florić, 2011: 37). Koliki će osećaj socijalne uključenosti ili socijalne isključenosti imati pojedinac zavisi i od samopercepcije (Goleman, 2010; Havelka, 2012). Danas se u psihologiji, sociologiji i pedagogiji pridaje velika važnost samopoimanju. „Uistinu se misli da je ponašanje racionalnije ako su ljudi razmišljali o svojim motivima, namerama itd." (Pennington, 2008: 150). Zapravo, naše percepcije često postaju uzroci brojnim posljedicama koje se javljaju u odnosima sa drugim ljudima ili grupama. Popuštanje i konformizam imaju veliki značaj u uspostavljanju socijalne uključenosti i socijalne isključenosti. Popuštanje možemo definisati kao reakciju pojedinca na zahteve drugog subjekta. Otuda je izuzetno bitna vrsta zahteva koja se postavlja pred pojedinca. Koliko, kada i zbog čega pojedinac hoće ili neće popustiti pred pritiskom drugih zavisi i od njegovih kompetencija, osobina, stavova, uverenja i slično. Tako Donald Pennington (2008) smatra da se konformizam, za razliku od popuštanja, ispoljava dvojako:

a) kao promena ponašanja prema društvenoj grupi ili normi i

b) kao pritisak grupe ljudi, a ne zahtev pojedinca. 
U procesu „prevođenja” pojedinca iz stanja socijalne isključenosti u prihvatljivu socijalnu uključenost od izuzetne pomoći je proces i sistem socijalne integracije. Ta integracija je potrebna „osobama koje nisu uključene, koje manifestuju poteškoće pri uključivanju u uobičajenu društvenu sredinu ili pri uključivanju u specifična područja društvenih aktivnosti” (Uzelac i Bouillet, 2007: 44).

Socijalni odnosi su od izuzetnog značaja za pojedinca, jer predstavljaju posebnu dimenziju njegovog socijalnog života. U socijalnim odnosima pojedinac formira sliku o sebi, stiče nove socijalne veštine, razvija socijalne kompetencije, zadovoljava lične potrebe za bliskošću, uči pomagati, deliti, sarađivati, prihvatati druge i takođe biva prihvaćen od drugih.

\section{Metodologija istraživanja}

Proučavanjem relevantne literature o socijalnoj uključenosti i socijalnoj isključenosti izabrali smo predmet i cilj koji su u fokusu ovog empirijskog istraživanja. Predmet istraživanja je da se na osnovu samoprocene socijalnog statusa studenata postupkom faktorske analize identifikuju faktori njihove socijabilnosti. Na osnovu predmeta istraživanja, definisali smo cilj istraživanja i konkretizovali istraživački zadatak. Cilj istraživanja je da se konstruiše skala za merenje socijabilnosti studenata, te da identifikujemo faktore koji determinišu njihovu socijabilnost.

Ispitivanje je sprovedeno na uzorku od 222 studenta starosti između 19 i 28 godina $(M=22,41$; $\mathrm{SD}=1,66)$. Uzorak čine studenti od prve do četvrte godine studija pedagoških usmerenja na Filozofskom fakultetu u Banjoj Luci ( $N=101)$ i Filozofskom fakultetu u Nišu $(\mathrm{N}=121)$. Pored pisanog uputstva u istraživačkom instrumentu, prije početka ispitivanja, ispitanicima su objašnjeni značaj i svrha istraživanja i ukazano je na pedagošku vrednost upotrebe rezultata. Obavljeno je grupno ispitivanje, a učešće je u potpunosti bilo dobrovoljno i anonimno.

Tehnikom skaliranje primenili smo Skalu za ispitivanje socijalne uključenosti i socijalne isključenosti SISUSI (skala Likertovog tipa sa pet stepena procene). U okviru ove tehnike kreiran je instrument, kojim smo nastojali na osnovu samoprocena studenata da identifikujemo faktore socijalne uključenosti i socijalne isključenosti. Prva varijanta instrumenta sastojala se od 72 ajtema koji se odnose na različite aspekte socijabilnosti. Nakon obrade prvih podataka zadržano je 26 ajtema. Konačnu varijantu instrumenta čine dve zasebne skale, socijalna uključenost sa 12 i socijalna isključenost sa 14 ajtema. Utvrdili smo koeficijente relijabilnosti $\alpha=0,83$ za skalu socijalne uključenosti i $\alpha=0,86$ za skalu socijalne isključenosti.

\section{Rezultati i diskusija}

Nakon primene Skale za ispitivanje socijalne uključenosti i socijalne isključenosti - SISUSI pristupili smo postupku faktorske analize koristeći metodu glavnih komponenti (principal component analysis, PCA). Kriterijumi za ekstrakciju broja faktora bili su Kajzer-Gutmanov kriterijum (Kaiser-Guttman) za vrednost karakterističnog korena (vrednost najmanje 1), Katelov test odrona (Cattell scree plot), sa što manjim brojem faktora (Pallant, 2009). Primenjujući pomenute kriterijume, dobili smo više različitih modela koji zadovoljavaju elementarne statističke uslove (Cohen, Manion, Morison, 2007). Istovremeno smo tretirali sve varijable $i$ ispitanike $u$ istraživanju kako bismo dobili jedinstven skup međusobno povezanih podataka (Fajgelj, 2020). Rezultat primene ovih kriterijuma i naknadnih rotacija jeste više modela, od kojih će jedan biti interpretiran u ovom radu (Grafikon 1). 


\section{Grafikon 1. Katelov test odrona}

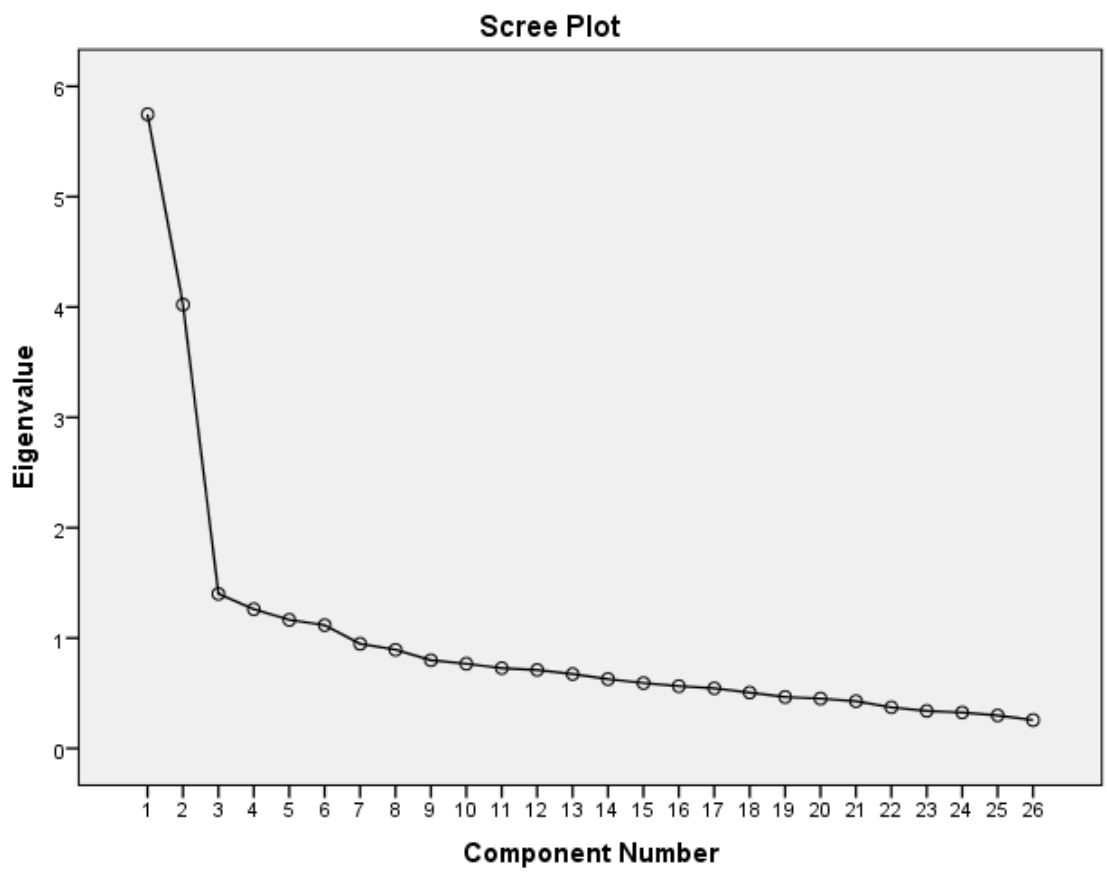

Odabranim empirijskim modelom pokušaćemo objasniti šta čini aspekte socijabilnosti studenata. $U$ Tabeli 1. uočavamo da u ovom modelu imamo dva faktora (komponente), koji učestvuju u objašnjenju $37,57 \%$ ispitivane pojave. Primenjena skala procene za merenje stavova studenata o socijalnoj uključenosti $i$ isključenosti ima prihvatljive merne karakteristike, što zaključujemo na osnovu kumulativnog procenta, kao i procenta objašnjene varijanse za svaki ekstrahovani faktor pojedinačno.

Tabela 1. Faktorski model socijalne uključenosti i socijalne isključenosti studenata

\begin{tabular}{lccc}
\hline Komponente & $\begin{array}{c}\text { Svojstvena } \\
\text { vrednost }\end{array}$ & $\begin{array}{c}\text { Postotak objašnjene } \\
\text { varijanse }\end{array}$ & $\begin{array}{c}\text { Kumulativni postotak } \\
\text { varijanse }\end{array}$ \\
\hline Socijalna uključenost & 5,74 & 22,10 & 22,10 \\
\hline Socijalna isključenost & 4,02 & 15,46 & 37,57 \\
\hline
\end{tabular}

Prikazani rezultati ukazuju da socijalna kompetencija studenata obuhvata razvijene sledeće komponente: socijalnu uključenost i socijalnu isključenost. Izdvojene skale sa sumativnim skorovima pokazuju korelaciju r=0,99, što ukazuje na visok koeficijent povezanosti.

Naredni korak u statističkoj analizi koji smo koristili jeste prikaz glavnih komponenti, odnosno zasićenja pojedinačnih stavki sa ključnim faktorima u rotiranoj matrici faktorske strukture samoprocena studenata o socijalnoj uključenosti i socijalnoj isključenosti. 
Tabela 2. Rotirana matrica faktorske strukture socijalne uključenosti i

socijalne isključenosti studenata (promaks rotacija)

\begin{tabular}{|c|c|c|}
\hline & \multicolumn{2}{|c|}{ Komponente } \\
\hline & $\begin{array}{c}\text { Socijalna } \\
\text { isključenost }\end{array}$ & $\begin{array}{c}\text { Socijalna } \\
\text { uključenost }\end{array}$ \\
\hline Usvojio/la sam različite socijalne veštine. & & .497 \\
\hline Za vreme komunikacije sa drugom osobom mogu uspostaviti kontakt očima. & & .534 \\
\hline Kada se sa nekim rukujem, nasmešim mu se. & & .500 \\
\hline Prilikom susreta sa nekim rukujem se. & & .583 \\
\hline Lako opažam tuđe emocije. & & .537 \\
\hline Sa razvojem socijalnih veština povećava se samopouzdanje. & & .537 \\
\hline Ne znam kako adekvatno reagovati u određenoj situaciji. & .585 & \\
\hline Teško mi je komunicirati sa svim profesorima i asistentima. & .560 & \\
\hline Mogu proceniti kada je napeta situacija. & & .704 \\
\hline Vodim računa kada izražavam svoje mišljenje pred drugim ljudima. & & .695 \\
\hline Kolege mi kažu da sam pozitivan lik. & & .623 \\
\hline Realno se predstavljam. & & .703 \\
\hline Rado sam viđen gost. & & .600 \\
\hline Trudim se da budem dobar domaćin. & & .612 \\
\hline Izbegavam interakciju sa većim brojem ljudi. & .723 & \\
\hline U pojedinim aktivnostima kolege me izbegavaju. & .723 & \\
\hline U određenim situacijama ispoljavam nesigurnost. & .636 & \\
\hline Povlačim se pred autoritetom. & .698 & \\
\hline Ne volim slavlja u porodici i rodbini. & .681 & \\
\hline Neprijatno mi je kada neko nadgleda dok nešto radim. & .551 & \\
\hline Krijem prosek ocena na fakultetu. & .588 & \\
\hline Na fakultet i sa fakulteta odlazim sam/a. & .481 & \\
\hline Kada usmeno odgovaram na ispitu, volim da sam sam/a. & .482 & \\
\hline Povlačim se kada mi upute kritiku. & .681 & \\
\hline Pojedinci me loše procenjuju. & .445 & \\
\hline Kada nemam novca, ne izlazim sa kolegama. & .533 & \\
\hline
\end{tabular}

Za izdvajanje ajtema koji ulaze u konačnu verziju matrice faktorske strukture koristili smo promaks rotaciju. U Tabeli 2. prikazana su faktorska zasićenja, koja se kreću u rasponu od 0,48 do 0,72, a napominjemo da ajteme sa zasićenjima manjim od o,40 nismo uzeli u obzir. Na osnovu rotirane matrice fakorske strukture socijalne uključenosti i socijalne isključenosti studenata identifikovali smo dve komponente (faktora). Dobijene vrednosti nam pokazuju da smo konstruisali metodološki prihvatljiv instrument. Dobijene faktore smo imenovali prema sadržinskim kriterijumima pojedinačnih tvrdnji.

Tabela 3. Statistički pokazatelji identifikovanih faktora

\begin{tabular}{lll}
\hline & Socijalna uključenost & Socijalna isključenost \\
\hline $\mathbf{M}$ & 50,31 & 39,81 \\
\hline SD & 5,98 & 10,93 \\
\hline K-S & $1,50^{*}$ & 1,10 \\
\hline$S_{k}$ & $-0,96$ & 0,52 \\
\hline
\end{tabular}




\begin{tabular}{|c|c|c|}
\hline $\mathrm{K}_{\mathrm{u}}$ & 1,21 & 0,25 \\
\hline $\mathbf{N}$ & 222 & 222 \\
\hline $\begin{array}{l}\mathrm{K}-\mathrm{S} \\
\mathrm{S}_{\mathrm{k}}-\mathrm{S} \\
{ }^{*} \text { nivo }\end{array}$ & $\begin{array}{l}\text { ggoro } \\
\text { urto } \\
0,05\end{array}$ & \\
\hline
\end{tabular}

U Tabeli 3. prikazani su osnovni statistički pokazatelji za identifikovane faktore, na osnovu kojih uočavamo da studenti imaju pozitivnu procenu socijalne uključenosti $(M=50,31)$ i neutralnu procenu socijalne isključenosti $(M=39,81)$. Utvrđena aritmetička sredina na subskali socijalna isključenost podeljena sa ukupnim brojem ajtema (12) pokazuje da prosečna vrednost stava studenata iznosi 4,19 što predstavlja pozitivan stav, dok aritmetička sredina na subskali socijalna isključenost podeljena sa ukupnim brojem ajtema (14) pokazuje da prosečna vrednost stava studenata iznosi 2,84 što implicira da se radi o približno neutralnom stavu. Na osnovu standardne devijacije $(S D=10,93)$ zaključujemo da se kod socijalne isključenosti radi o većoj raspršenosti stavova studenata, što ukazuje da između tih studenata postoje veće socijalne i druge razlike, udaljenosti, manja homogenost i slično. Polazeći od samopercepcija studenata o socijalnoj uključenosti i socijalnoj isključenosti pretpostavljamo da kod većine ispitanika dominira jedna od utvrđenih dimenzija.

\section{Zaključak}

Polazeći od namere autora da konstruišu instrument koji meri socijalnu uključenost i/ili socijalnu isključenosti, sastavljena je prva verzija mernog instrumenta koja je obuhvatila 72 tvrdnje. Postupkom faktorske analize utvrđena su dva faktora - socijalna uključenost i socijalna isključenost. Konačna verzija mernog instrumenta sadrži 26 tvrdnji i određena je sa dve zasebne subskale, socijalna uključenost sa 12 i socijalna isključenost sa 14 ajtema. Koeficijenti pouzdanosti za obe skale su zadovoljavajući, $a=0,83$ za subskalu socijalne uključenosti i $a=0,86$ za subskalu socijalne isključenosti. Proverom diskriminativnosti mernog instrumenta utvrđeno je da postoji pomeranje skorova prema višim vrednostima na subskali socijalne uključenosti $(\mathrm{S}=-0,97, \mathrm{Ku}=1,12)$, za razliku od distribucije skorova na subskali socijalne isključenosti koja prema istim parametrima ne odstupa značajno od normalne $(S=0,52, K u=0,25)$. Kolmogorov-Smirnov test $(K-S=1,50, p<.05)$ potvrđuje statistički značajno odstupanje skorova od normalne distribucije na subskali socijalne uključenosti. Obe subskale sa sumativnim skorovima ostvaruju korelaciju $r=0,99$.

Preliminarni rezultati ukazuju da su utvrđene statističke karakteristike Skale za ispitivanje socijalne uključenosti i socijalne isključenosti - SISUSI zadovoljavajuće. Naredni koraci u nastojanju da se postigne potpuna validacija skale i njenog korištenja kao pouzdanog istraživačkog instrumenta podrazumeva proveru skale na drugim uzorcima i proveru odnosa sa relevantnim spoljnim kriterijskim varijablama. Preporučujemo primenu instrumenta u različitim obrazovno-vaspitnim institucijama. Poželjno je da budući istraživači konačnu verziju instrumenta prilagođavaju specifičnostima izabrane populacije i uzorka. 


\section{Prilog - Konačna verzija mernog instrumenta}

\section{Socijalna uključenost i/ili isključenost}

Poštovani,

Ovom skalom želimo da utvrdimo stavove o socijalnoj uključenosti i socijalnoj isključenosti. Pažljivo čitajte tvrdnju po tvrdnju i u skladu sa stepenom slaganja zaokružite odgovarajući broj. Uvek imajte na umu da se isključivo radi o Vama. Primena skale je anonimna.

1. Studijski program:
a) pedagogija
b) predškolsko vaspitanje
c) učiteljski studij

2. Godina studija:

3. Pol:

$\begin{array}{ll}\text { II } & \text { III } \\ \check{Z} & \mathrm{M}\end{array}$

IV

1 - uopšte se ne slažem, 2 - uglavnom se ne slažem, 3-neodlučan sam,

4- uglavnom se slažem, 5 - u potpunosti se slažem

\begin{tabular}{|c|c|c|c|c|c|c|}
\hline 1. & Usvojio/la sam različite socijalne veštine. & 1 & 2 & 3 & 4 & 5 \\
\hline 2. & Za vreme komunikacije sa drugom osobom mogu uspostaviti kontakt očima. & 1 & 2 & 3 & 4 & 5 \\
\hline 3. & Kada se sa nekim rukujem, nasmešim mu se. & 1 & 2 & 3 & 4 & 5 \\
\hline 4. & Prilikom susreta sa nekim rukujem se. & 1 & 2 & 3 & 4 & 5 \\
\hline 5. & Lako opažam tuđe emocije. & 1 & 2 & 3 & 4 & 5 \\
\hline 6. & Sa razvojem socijalnih veština povećava se samopouzdanje. & 1 & 2 & 3 & 4 & 5 \\
\hline 7. & Ne znam kako adekvatno reagovati u određenoj situaciji. & 1 & 2 & 3 & 4 & 5 \\
\hline 8. & Teško mi je komunicirati sa svim profesorima i asistentima. & 1 & 2 & 3 & 4 & 5 \\
\hline 9. & Mogu proceniti kada je napeta situacija. & 1 & 2 & 3 & 4 & 5 \\
\hline 10. & Vodim računa kada izražavam svoje mišljenje pred drugim ljudima. & 1 & 2 & 3 & 4 & 5 \\
\hline 11. & Kolege mi kažu da sam pozitivan lik. & 1 & 2 & 3 & 4 & 5 \\
\hline 12. & Realno se predstavljam. & 1 & 2 & 3 & 4 & 5 \\
\hline 13. & Rado sam viđen gost. & 1 & 2 & 3 & 4 & 5 \\
\hline 14. & Trudim se da budem dobar domaćin. & 1 & 2 & 3 & 4 & 5 \\
\hline 15. & Izbegavam interakciju sa većim brojem ljudi. & 1 & 2 & 3 & 4 & 5 \\
\hline 16. & U pojedinim aktivnostima kolege me izbegavaju. & 1 & 2 & 3 & 4 & 5 \\
\hline 17. & U određenim situacijama ispoljavam nesigurnost. & 1 & 2 & 3 & 4 & 5 \\
\hline 18. & Povlačim se pred autoritetom. & 1 & 2 & 3 & 4 & 5 \\
\hline 19. & Ne volim slavlja u porodici i rodbini. & 1 & 2 & 3 & 4 & 5 \\
\hline 20. & Neprijatno mi je kada neko nadgleda dok nešto radim. & 1 & 2 & 3 & 4 & 5 \\
\hline 21. & Krijem prosek ocena na fakultetu. & 1 & 2 & 3 & 4 & 5 \\
\hline 22. & Na fakultet i sa fakulteta odlazim sam/a. & 1 & 2 & 3 & 4 & 5 \\
\hline 23. & Kada usmeno odgovaram na ispitu, volim da sam sam/a. & 1 & 2 & 3 & 4 & 5 \\
\hline 24. & Povlačim se kada mi upute kritiku. & 1 & 2 & 3 & 4 & 5 \\
\hline 25. & Pojedinci me loše procenjuju. & 1 & 2 & 3 & 4 & 5 \\
\hline 26. & Kada nemam novca, ne izlazim sa kolegama. & 1 & 2 & 3 & 4 & 5 \\
\hline
\end{tabular}




\section{Literatura:}

Cohen, L., Manion, L., Morison, K. (2007). Metode istrazivanja u obrazovanju. Zagreb: Naklada Slap.

Fajgelj, S. (2020). Metode istrazivanja ponasanja (VII dopunjeno izdanje). Beograd: Centar za primenjenu psihologiju.

Goleman, D. (2010). Socijalna inteligencija. Beogard: Geopolitika.

Havelka, N. (2012). Socijalna percepcija. Beograd: Zavod za udzbenike.

Jevtic, B. i Knezevic-Floric, B. (2011). Izazovi socijalnopedagoske delatnosti. Nis: Filozofski fakultet.

Klarin, M. (2004). Uloga socijalne podrske vrsnjaka i vrsnjackih odnosa u usamljenosti predadolescenata i adolescenata. Drustvena istrazivanja, 6(74), 1081-1097.

Kobolt, A. (2010). Socijalnopedagosko procenjivanje i intervenisanje. U Socijalna pedagogija u nastajanju - trazenje odgovora na probleme drustveno iskljucenih grupa, 85-105. Pedagoski fakultet u Jagodini.

Krnjajic, S. (2002). Socijalni odnosi i obrazovanje. Beograd: Institut za pedagoska istrazivanja.

Macura-Milovanovic, S. (2010). U trazenju odgovora na problem drustveno iskljucenih grupa u Srbiji. $\mathrm{U}$ Socijalna pedagogija u nastajanju - trazenje odgovora na probleme drustveno iskljucenih grupa, 171-19o. Pedagoski fakultet u Jagodini.

Pallant, J. (2009). SPSS prirucnik za prezivljavanje: postupni vodic kroz analizu podataka pomocu SPSS-a za Windows (verzija 15). Beograd: Mikro knjiga.

Pennington, C. D. (2008). Osnove socijalne psihologije. Jastrebarsko: Naklada.

Sucur, Z. (2004). Socijalna iskljucenost: pojam, pristupi i operacionalizacija, Revija za sociologiju, 35 (1-2), 45-60.

Urbanc, K. (2006). Izazovi socijalnog rada s pojedincem. Zagreb: Alinea.

Uzelac, S. i Bouillet, D. (2007). Osnove socijalne pedagogije. Zagreb: Skolska knjiga.

Zubac, J. (2020). Problem definisanja i operacionalizacije pojma socijalna iskljucenost. Kultura, (166), 316-336.

\section{Biografske beleške o autorima:}

Brane Mikanović je doktor pedagoških nauka i vanredni profesor na Filozofskom fakultetu Univerziteta u Banjoj Luci za užu naučnu oblast Opšta pedagogija. Područja njegovog interesovanja su: fundamentalna pitanja pedagoške nauke, teorije vaspitanja, medijsko vaspitanje, socijalna promocija i izolacija vaspitanika, vaspitanje u slobodnom vremenu i za slobodno vrijeme, vršnjačko nasilje, kvalitet udžbenika i istraživački rad učenika. Autor je preko pedeset stručnih i naučnih radova iz navedenih oblasti, objavio je nekoliko knjiga: Istraživački rad učenika - teorijske osnove i modeli, Naučni razvoj pedagogije i područja vaspitanja, Osnove pedagogije, Vaspitanje i slobodno vrijeme i (Ne)disciplina u vaspitanju.

Kristijan Popović je viši asistent na Filozofskom fakultetu Univerziteta u Banjoj Luci za užu naučnu oblast Opšta pedagogija. Angažovan je na više studijskih programa Filozofskog fakulteta. Autor je i koautor više naučnih radova, naučne monografije, učesnik seminara, projekata i naučnih skupova. Oblast njegovog interesovanja je interkulturalno vaspitanje i obrazovanje, interkulturalne kompetencije, vršnjačko nasilje i slobodno vrijeme djece i mladih. Trenutno pohađa treći ciklus studija pedagogije (doktorske studije) istog fakulteta. 